DOI https://doi.org/10.18551/rjoas.2018-04.25

\title{
FACTORS INFLUENCE TO HOTEL TAX COMPLIANCE IN DENPASAR CITY
}

\author{
Desmayani Ni Made Mila Rosa, Budiartha Ketut \\ Department of Accounting, Faculty of Economics and Business, Udayana University, \\ Denpasar, Indonesia \\ *E-mail: milarosadesmayani@yahoo.co.id
}

\begin{abstract}
The purpose of this study is to determine the effect of understanding the rules of taxation, distributive justice, tax administration, moral obligations, and tax sanctions against tax compliance. The study was conducted in Denpasar City with hotels' owners or general managers as respondents. The results of analysis show that understanding of taxation regulation and distributive justices have positive effect on Denpasar tax compliance.
\end{abstract}

\section{KEY WORDS}

Understanding of taxation, distributive justice, tax administration compliance, moral obligations, taxation sanctions.

Local Own Revenue is an important capital in regional development besides General Allocation Fund and other governmental. Potential sources of revenue in financing regional development should be maximized by local governments due to the implementation of regional autonomy. As a tourist destination, contribution of hotel tax on Province and Regency in Bali is quite big. So that the tax compliance, especially the field of hotels will be able to increase local revenue. Compliance is an attitude by willingness to carry out a behavior, based on awareness or coercion, so as to make a person's behavior in accordance with what is expected (Mc Mahon, 2001).

Since 2013 Denpasar Revenue Board started to implement self-assessment system on the implementation of hotel taxation. In such a system, the taxpayer is given the authority, trust, responsibility to the taxpayer in calculating, paying and reporting his own taxable amount payable (Ilyas \& Burton, 2011). Implementation of the self-assessment system, taxpayers are more likely to utilize the trust given by the government and do not perform the provisions of taxation well. Law No. 28 of 2009 on Regional Taxes and Levies states that there are 16 types of local taxes consisting of 5 provincial taxes and 11 districts / cities taxes.

Provincial and regency / municipal governments are given full authority to explore the objects of local taxes to be a source of revenue in the form of local taxes. The fraud done by the taxpayer in making the tax payment that is not calculate well and true income it receives, and there is still a lot of increase hotel addition which is not matched with tax payment from taxpayer, and accumulation of arrears from previous so causing swelling of tax to taxpayer. Research on tax compliance has been done, using variable of understanding of taxation, distributive justice, tax administration, moral obligation, and taxation sanction.

\section{THEORY AND DEVELOPMENT OF HYPOTHESES}

Theory of Legitimacy. Ghozali (2007) describes the theory of legitimacy as a value system of entities in line with the social value of society. If in a system in an entity the absence of harmony with the value system of society, then the entity will lose its legitimacy that can complicate the survival of the entity. O'Donovan (2007) argues that legitimacy is considered to equate perceptions or assumptions that actions taken by the entity are normal and aligned in accordance with applicable regulations.

Rohmawati (2012) taxpayer compliance can be influenced by the level of understanding of taxpayers of the applicable taxation legislation. Understanding the rules can foster a positive attitude of the taxpayer if they are well aware of the contents of tax laws that 
often change. Understanding the regulation is expected to generate high self-awareness for taxpayers to perform their obligations as taxpayers voluntarily obey.

$\mathrm{H} 1$ : the understanding of tax laws has a positive effect on taxpayer compliance of hotels in Denpasar city.

Theory of Justice. Robbins (2008) states the theory of justice will be given by someone after considering the efforts undertaken and the results of tax obligations by the taxpayer and consider other taxpayers. Taxpayers respond to injustice against them by non-compliance with their tax obligations. Budhiarsana (2011) concluded that taxpayer compliance is positively influenced by distributive justice.

Budhiarsana (2011) study supports the results of the Albari (2013) study which found that taxpayer compliance is influenced by distributive justice. Existence of consideration of paying taxes and getting good service from the income board, taxpayers will react to his perception of distributive justice that obediently fulfill his obligations. Distributive justice and taxpayer compliance were found by Albari (2008), Mahasena (2017). Verboon and Goslinga (2009) find distributive justice not to have a significant effect on entrepreneurs with high personal norms. Taking into account the payment of taxes in exchange for services from Dispenda, taxpayers will react to their perception of distributive justice by adhering to tax obligations.

H2: Distributive Justice has a positive effect on hotel taxpayer compliance in Denpasar city.

Theory of Legitimacy. Ghozali (2007) describes the theory of legitimacy as a value system of entities in line with the social value of society. System in an entity the absence of harmony with the value system of society, then the entity will lose its legitimacy that can complicate the survival of the entity. O'Donovan (2007) argues that legitimacy is considered to equate perceptions or assumptions that actions taken by the entity are normal and aligned in accordance with applicable regulations.

Rahayu (2009) taxpayer compliance can be influenced by several factors namely the state tax administration system of a country, services provided to taxpayers, law enforcement taxation, tax audit and tax rates applicable. Simple taxation system is very important because the more complex the tax system will affect taxpayer compliance. Existing system has given satisfaction to the taxpayer will be more compliant in carrying out its tax obligations. Fujihana (2012) the purpose of tax administration is to assist in the development of voluntary tax compliance. Taxpayer compliance will continue if supported by effective administration. Harinurdin (2011) also argues that the simplicity of tax laws is very important, because it facilitates the administration system and compliance / tax compliance and helps in achieving maximum tax revenue.

H3: tax administration has a positive effect on hotel taxpayer compliance in Denpasar city.

Moral obligation. Ghozali (2007) describes the Theory of Legitimacy as a value system of entittas in line with the social value of society. System in an entity the absence of harmony with the value system of society, then the entity will lose its legitimacy that can complicate the survival of the entity. O'Donovan (2007) argues that legitimacy is considered to equate perceptions or assumptions that actions taken by the entity are normal and aligned in accordance with applicable regulations.

Moral obligation of a person must have individual norms in carrying out everything, such as ethics and principles (Ajzen, 2002). It can be attributed to the compliance of the taxpayer to meet all tax obligations, especially paying hotel taxes. Mustikasari (2007) and Pranata (2015) proves moral obligation to have a positive and significant influence on taxpayer compliance. Moral obligations that exist in the taxpayer high causing the intention of non-tax compliance low. Moral community will affect tax collection by tax authorities. With high integrity of course the fulfillment of tax obligations will be better. Taxpayer compliance will be more better if the morale of the population is good. The desire to escape tax both illegally and relieved is motivated by the low morale of society. Poor community morale will hamper tax collection, noncompliance will dominate taxpayers' tax obligations (Muthia, 2014). 
H4: Moral obligation affects positively on hotel taxpayer compliance in Denpasar city.

Attribution Theory. Events are interpreted by a person and examine the interpretation of the reasons and the causes. The relationship with tax sanctions in the form of strict sanctions and felt to be fair for all taxpayers is very necessary, distributive justice is deemed very necessary in providing services to taxpayers to assist in payment, do not discriminate the taxpayer, so that all taxpayers feel satisfaction the same from one another. Moral obligation is the norm of an individual possessed by a person, but may not belong to another. Tax sanctions are a guarantee that the provisions of the tax laws and regulations will be obeyed or obeyed or observed, in other words, tax penalties are a means of preventing taxpayers from violating taxation norms (Mardiasmo, 2011: 59). In the tax law there are two types of sanctions, in the form of criminal sanctions and administration. Tax sanctions imposed on taxpayers who are not compliant in fulfilling their taxation.

Yulayca (2013) in his research states that tax sanctions have a positive effect on taxpayer compliance. Taxpayers are likely to be obedient to their tax obligations if the applied fines sanctions cause more losses. The greater amount of tax arrears that are owned and must be paid by the taxpayer, the more weight will be burden for the taxpayer in the repayment. Layata and Setiawan (2014) and Sanjaya (2014) found that the better perceptions of enforcement of sanctions received by taxpayers will lead to increased taxpayer compliance in terms of carrying out all tax obligations. This opinion supports the research of Jatmiko (2006) and Koentarto (2011) which proves that tax sanctions have a positive effect on taxpayer compliance.

H5: tax sanctions have a positive effect on hotel taxpayer compliance in Denpasar city.

\section{METHODS OF RESEARCH}

This research uses quantitative approach in associative form. Quantitative research is a study that emphasizes theoretical testing through measurement of research variables with numbers and data analyzed using statistical procedures (Indriantoro \& Supomo, 2013). Research in the form of associative is research that aims to know the relationship between two variables or more (Sugiyono, 2013).

Data source used in this research is primary data. Primary data collected by using questionnaires containing statements distributed to respondents are hotel taxpayers. Nonparticipant observation is data collection technique where the researcher is not involved and only as a free observer (Sugiyono, 2013: 204). In this study, the data obtained from documentation techniques such as the list of hotel tax arrears in Denpasar Revenue Agency, as well as using Likert scale.

Table 1 - Sample selection process

\begin{tabular}{lll}
\hline No & Information & Total \\
\hline 1 & Hotel Taxpayer & 83 \\
2 & Samples not return & $(0)$ \\
\hline & Total selected as sample & 83 \\
\hline
\end{tabular}

Source: data processed (2017).

$$
Y=\alpha+\beta_{1} X_{1}+\beta_{2} X_{2}+\beta_{3} X_{3}+\beta_{4} X_{4}+\beta_{5} X_{5}+\varepsilon
$$

Where:

- $\mathrm{Y}=$ Tax compliance;

- $\alpha=$ Constants;

- $\beta_{1}=$ Regression coefficient understanding of tax regulations;

- $\beta_{2}=$ Coefficient of tax administration regression;

- $\beta_{3}=$ Regression coefficient of tax sanction;

- $\beta_{4}=$ Regression coefficient Moral Obligation; 
- $\quad \beta_{5}=$ Regression coefficient of Tax Sanction;

- $\mathrm{X}_{1}=$ Understanding of tax laws;

- $\mathrm{X}_{2}=$ distributive justice;

- $\mathrm{X}_{3}=$ tax administration;

- $\mathrm{X}_{4}=$ Moral Liability;

- $\mathrm{X}_{5}=$ Tax Sanctions;

- $E=$ residual.

\section{RESULTS AND DISCUSSION}

Understanding of Tax Regulations as measured by discreonary accrual has a minimum value of 6.00. The maximum value is 21.63 and the mean is 16.625. Std Value. Deviation is 5,543 . Distributive Justice as measured by discreonary accrual has a minimum value of 3.00 . The maximum value is 10.85 and the mean is 8,200 . Std Value. The deviation is 2,808 . Tax Administration as measured by discreonary accrual has a minimum value of 14.00 . The maximum value is 52.63 and the mean is 39,054 . Std Value. The deviation is 12,490 . Moral duties measured with discreonary accruals have a minimum value of 4.00 . The maximum value of 15.26 and the mean of 10.913. Std Value. The deviation is 3.740. Taxation sanctions as measured by discreonary accruals have a minimum value of 5.00 . The maximum value of 18.55 and the mean of 13.413. Std Value. Deviation is 4.567.

Table 2 - Descriptive Analysis

\begin{tabular}{|c|c|c|c|c|c|}
\hline $\mathrm{n} / \mathrm{n}$ & $\mathrm{N}$ & Minimum & Maximum & Mean & Std. Deviation \\
\hline $\mathrm{X} 1$ & 83 & 6 & 21,63 & 16,6259 & 5,54395 \\
\hline $\mathrm{X} 2$ & 83 & 3 & 10,85 & 8,2005 & 2,80833 \\
\hline $\mathrm{X} 3$ & 83 & 14 & 52,63 & 39,054 & 12,49075 \\
\hline $\mathrm{X} 4$ & 83 & 4 & 15,26 & 10,9133 & 3,74086 \\
\hline $\mathrm{X} 5$ & 83 & 5 & 18,55 & 13,4317 & 4,56763 \\
\hline $\mathrm{Y}$ & 83 & 5 & 17,88 & 13,7672 & 4,8495 \\
\hline
\end{tabular}

Source: data processed (2017).

Table 3 - Simple Linear Regression Analysis Result

\begin{tabular}{|c|c|c|c|c|}
\hline Variable Name & Regression Coefficient & Std. Coefficient Beta & $\mathrm{t}$ & Sig. \\
\hline influence of tax understanding & 0,174 & 0,198 & 2,095 & 0,039 \\
\hline distributive justice & 0,369 & 0,213 & 2,078 & 0,041 \\
\hline tax administration & 0,084 & 0,217 & 2,324 & 0,023 \\
\hline moral liability & 0,228 & 0,176 & 1,999 & 0,049 \\
\hline tax sanction & 0,201 & 0,189 & 2,059 & 0,043 \\
\hline Constants & \multicolumn{4}{|c|}{$-0,620$} \\
\hline Adjusted $\mathrm{R}$ square & \multicolumn{4}{|c|}{0,668} \\
\hline $\mathrm{F}_{\text {Hitung }}$ & \multicolumn{4}{|c|}{34,034} \\
\hline F Sig & \multicolumn{4}{|c|}{0,000} \\
\hline Linear Regression Analysis & \multicolumn{4}{|c|}{$Y=-0,620+0,174\left(X_{1}\right)+0,369\left(X_{2}\right)+0,084\left(X_{3}\right)+0,228\left(X_{4}\right)+0,201\left(X_{5}\right)$} \\
\hline
\end{tabular}

Source: SPSS, 2017.

Hypothesis test the influence of tax understanding variable to tax compliance. Since the Sig value is $0.039 \leq 0.05$ with the value of $2.095, \mathrm{H} 1$ is accepted. This means that the variable of tax understanding has a positive effect on tax compliance variable. Hypothesis test of influence of distributive justice variable to tax compliance. Therefore the Sig value of $0.041 \leq 0.05$ with the value of $2.078, \mathrm{H} 2$ is accepted. This means that distributive justice variables have a positive effect on variable tax compliance. Hypothesis test the influence of tax administration variable to tax compliance. Because the value of Sig $0,023 \leq 0,05$ value 2,324, H3 accepted. This means that tax administration variables have a positive effect on variable tax compliance. Test the hypothesis of the influence of the moral liability variable to tax compliance. Therefore the Sig value of $0.049 \leq 0.05$ value $1.999, \mathrm{H} 4$ is accepted. This means that the variable of moral obligation has a positive effect on tax compliance variable. 
Hypothesis test the influence of tax sanction variable to tax compliance. Since the Sig value of $0.043 \leq 0.05$ value $2.059, \mathrm{H} 5$ is accepted. This means that the tax sanction variable has a positive effect on tax compliance variable.

\section{DISCUSSION OF RESULTS}

Influence of Tax Understanding and Tax Compliance. Understanding the rules can foster a positive attitude of the taxpayer if they are well aware of the contents of tax laws that often change. Understanding the regulation is expected to generate high self-awareness for taxpayers to perform their obligations as taxpayers voluntarily obey. The existence of good regulatory understanding, the higher the level of taxpayer compliance in the fulfillment of tax obligations.

Hypothesis that express understanding of taxation regulation have positive effect to tax compliance, $\mathrm{H} 1$ accepted. The results of this study are consistent with the results of research conducted by Rohmawati (2012), Gautama and Suryono (2014) taxpayer compliance can be influenced by the level of understanding of taxpayers of the applicable taxation legislation. Understanding the rules can foster a positive attitude of the taxpayer if they are well aware of the contents of tax laws that often change. Understanding the regulation is expected to generate high self-awareness for taxpayers to perform their obligations as taxpayers voluntarily obey.

The Effect of Distributive Justice and Tax Compliance. The existence of consideration of paying taxes and getting good service from the Income Board, taxpayers will react to his perception of distributive justice that obediently fulfill his obligations. The better level of service provided by the taxpayer to the taxpayer, the higher the taxpayer's interest in fulfilling his tax obligations.

Hpothesis disequal justice exerted positive effect on tax compliance, $\mathrm{H} 2$ accepted. The results of this study are consistent with the results of research conducted by Budhiarsana (2011), Albari (2008), Verbon and Goslinga (2009) Considering the payment of taxes in exchange for services from Dispenda, taxpayers react to their perceptions of distributive justice by compliance with obligations taxation.

The Effect of Moral Liability and Tax Compliance. The hypothesis that tax administration affects positively to tax compliance, H3 accepted. The results of this study consistent with the results of research conducted by Rahayu (2009), Fujihana (2012), Harinurdin (2011) taxpayer compliance can be influenced by several factors namely the state tax administration system of a country, services provided to taxpayers, tax audits and applicable tax rates. Simple taxation system is very important because the more complex the tax system will affect taxpayer compliance. If the existing system has given satisfaction to the taxpayer, the taxpayers themselves will be more compliant in carrying out its tax obligations. Community morale will affect tax collection by the tax authorities. High integrity of course fulfillment of tax obligation will be better. Taxpayer compliance will be more better if the morale of the population is good.

The Effect of Tax Administration and Tax Compliance. Taxpayer compliance will continue if supported by effective administration, the simplicity of tax laws is essential, as it facilitates administrative systems and compliance / tax compliance and helps in achieving adequate tax revenues and improving progress. The simpler administrative rules made by the government for the taxpayers, the more will increase the willingness of taxpayers in the fulfillment of tax obligations.

Hypothesis that moral obligation affects positively to tax compliance, $\mathrm{H} 4$ is accepted. The results of this study are consistent with the results of research conducted by Ajzen (2002), Mustikasari (2007), Pranata (2015), Muthia (2014) moral duties exist in a person must have individual norms in carrying out everything, ie ethics and principles Ajzen, 2002). It can be attributed to the compliance of the taxpayer to meet all tax obligations, especially paying hotel taxes. Mustikasari (2007) and Pranata (2015) proved moral obligation to have a positive and significant influence on taxpayer compliance. If the moral obligations that exist in the taxpayer high cause the intention of non-tax compliance is low. 
The Effect of Tax Sanctions and Tax Compliance. Greater the amount of tax arrears that are owned and must be paid by the taxpayer, the more weight will be burden for the taxpayer in the repayment. The better perceptions of enforcement of sanctions received by taxpayers will lead to increased compliance of taxpayers in terms of carrying out all tax obligations.

Hypothesis that moral obligation affects positively to tax compliance, $\mathrm{H} 5$ is accepted. The results of this study are consistent with the results of research conducted by Yulayca (2013), Layata and Setiawan (2014), Sanjaya (2014), Jatmiko (2006) and Koentarto (2011). Tax sanctions are a guarantee that the provisions of the tax laws and regulations will be obeyed or obeyed or observed, in other words, tax penalties are a means of preventing taxpayers from violating the taxation norms (Mardiasmo, 2011: 59). In the tax law there are two types of sanctions, in the form of criminal sanctions and administration. Tax sanctions imposed on taxpayers who are not compliant in fulfilling their taxation.

\section{CONCLUSION}

Based on the results of research on the understanding of taxation, distributive justice, tax administration, moral obligations, and tax sanctions on tax compliance PHR at the Hotel in Denpasar City, it can be concluded the understanding of tax regulations have a positive effect on tax compliance, this indicates taxpayer compliance may be affected by understanding of the taxpayer of the applicable taxation legislation. Understanding the regulation is expected to create a high self-awareness for taxpayers to carry out their obligations as voluntary taxpayer obligated. Distributive justice affects the tax compliance, it indicates the existence of consideration of paying taxes and getting good service from the Revenue Board, taxpayers will react to their perception of distributive justice that obediently fulfill their obligations. Tax administration affects the tax compliance, it indicates taxpayer compliance can be influenced by several factors, namely the condition of the tax administration system of a country, the services provided to the taxpayer, law enforcement taxation, tax audit and the applicable tax rate.

\section{REFERENCES}

1. Ademarta, Rio Septiadi. (2014). Pengaruh Modernisasi Sistem Administrasi Perpajakan Terhadap Tingkat Kepatuhan Pengusaha Kena Pajak Di Kantor Pelayanan Pajak (KPP) Pratama Padang dan Solo. Jurnal Ekonomi,2(1): 3-18.

2. Ajzen, Icek. (2002). Constructing a TpB Questionnaire: Conceptual and Methodological Considerations. Journal Time, 50(1): 179-211.

3. Albari. 2013. Pengaruh Keadilan Dan Pengetahuan Pajak Terhadap Kepatuhan Wajib Pajak. Jurnal Ilmu Sosial, 31(69):1-13.

4. Aminah, S. (2013). Pengaruh Penerapan Sistem Administrasi Perpajakan Modern Terhadap Kepatuhan Wajib Pajak Pada Kantor Pelayanan Pajak (KPP) Pratama Kota Surakarta.Journal of Chemical Information and Modeling, 53(9):1689-1699.

5. Ananggadipa, S. (2012).Studi Empiris Pada Penggunaan Aplikasi Pajak: Integrasi Theory Of Planned Behavior Dan Technology Acceptance Model (Studi Empiris Pada Perusahaan Go Public Di Indonesia). Skripsi. Universitas Diponegoro.

6. Budhiarsana, I Wayan., Dwirandra, A.A.N.B., Putra, I Nyoman Wijana Asmara. (2016). Kepuasan Sebagai Pemoderasi Pengaruh Keadilan Distributif, Penegakan Sanksi Pada Kepatuhan wajib Pajak Hotel Dan Restoran.E-Jurnal Akuntansi Universitas Udayana, 5(4): 53-62.

7. Chau, G., Leung, P. (2009). A Critical Review Of Fischer Tax Compliance Model: A Research Synthesis.Journal of Accounting and Taxation, 1(2): 034-040.

8. Dewi, A. A. S. I. K. (2016). Pengaruh Kesadaran, Kualitas Pelayanan, Kewajiban Moral, Dan Persepsi Sanksi Perpajakan Pada Kepatuhan Wajib pajak Reklame. E Journal Akuntansi Udayana, 17(1): 84-111.

9. Dewi, P. S. (2015). Faktor-Faktor Yang Mempenagruhi Kepatuhan Wajib Pajak Dalam 
Membayar Pajak Hotel. E-Jurnal Akuntansi Universitas Udayana, 13(2): 599-614.

10. Efferin, S., Stefanus Hadi Darmadji., Yuliawati Tan. (2008). Metode Penelitian Akuntansi. Yogyakarta: Graha IImu.

11. Fuandi, A. O. (2013). Pengaruh Kualitas Pelayanan Petugas Pajak, Sanksi Perpajakan dan Biaya Kepatuhan Pajak Terhadap Kepatuhan Wajib Pajak UMKM. Tax \& Accounting Review, 1: 18-27.

12. Fujihana, Y. (2012). Pengaruh Reformasi Pajak dan Sistem Administrasi Perpajakan Modern Terhadap Kepatuhan Wajib Pajak (Survei pada KPP Pratama Kota Bandung di Kanwil DJP Jabar 1). 1-25, www.google.scholar.co.id. Diunduh pada tanggal 20 Oktober 2017.

13. Gautama, M., Suryono, B. (2014). Analisis Faktor - Faktor Yang Mempengaruhi Kepatuhan Pajak Orang Pribadi Dalam Membayar Pajak. Jurnal IImu \& Riset Akuntansi, 3(12): 1-19.

14. Ghozali, Imam., Chariri. (2013). Teori Akuntansi. Semarang: BP UNDIP.

15. Hauptman, L., Horvat, M., Korez-Vide, R. (2014). Improving Tax Administration's Services As A Factor Of Tax Compilance: The Case Of Tax Audit. Lex Localis, 12(3): 481-501.

16. Harinurdin, E. (2011). Perilaku Kepatuhan Wajib Pajak Badan. Jurnal IImu Administrasi dan Organisasi, 16(2): 96-104.

17. Huang, J.H., Lin, C.Y. (2005). The Explanation Effects on Costumer PerceivedJustice, Satisfaction and Loyalty Improvement: An Exploratory Study. TheJournal of American Academy of Business, 7(2): 212-218.

18. Ilyas, Wirawan B., Ricard Burton. (2011).Hukum Pajak dan PerpajakanEdisi Kelima. Jakarta: Salemba Empat.

19. Indriyani, P. A. (2014). Tanggungjawab Moral, Kesadaran Wajib Pajak, Sanksi Perpajakan dan Kualitas Pelayanan Pada Kepatuhan Pelaporan Wajib Pajak Badan. Tax \& Accounting Review, 2: 431-443.

20. Irawan, D. (2017). Analisis Faktor-faktor Yang Mempengaruhi Tingkat kepatuha Pajak Wajib Pajak Badan Pada Perusahaan Industri Manufaktur Di Daerah Istimewa Yogyakarta. Diponegoro Journal Of Accounting,4(1): 20-38.

21. Jatmiko, A.N. (2006). Pengaruh Sikap Wajib Pajak Pada Pelaksanaan SanksiDenda, Pelayanan Fiskus Dan Kesadaran Perpajakan Terhadap Kepatuhan Wajib Pajak. Tesis. Universitas Diponegoro.

22. Kamil, Nurlis Islamiah. (2015). The Effect of Taxpayer Awareness, Knowledge, Tax Penalties and Tax Authorities Services on the Tax Compliance. Research Journal of Finance and accounting, 6 (2): 104-111.

23. Koentarto, I. (2011). Analisis Faktor-Faktor Yang Mempengaruhi Kepatuhan masyarakat Dalam Melakukan Pembayaran Pajak Bumi Dan Bangunan. Jurnal Ilmu-ilmu Sosial, 3(2): 243-258.

24. Layata, S., Setiawan, P. E. (2014). Pengaruh kewajiban moral, kualitas pelayanan, pemeriksaan pajak dan sanksi perpajakan pada kepatuhan wajib pajak badan. E-Jurnal Akuntansi Universitas Udayana, 2: 540-556.

25. Mahasena, I B P., Wirama, Dewa Gede., Ratnadi, Ni Made Dwi. (2017). Analisis FaktorFaktor Yang Mempengaruhi Kepatuhan Wajib Pajak Hotel di Kabupaten Gianyar. EJurnal Ekonomi dan Bisnis Universitas Udayana 6(3): 991-1018.

26. Mardiasmo. (2011).Perpajakan Edisi Revisi. Yogyakarta: Penerbit Andi.

27. (2013). Perpajakan Edisi Revisi 2013. Yogyakarta: Andi

28. McMahon, C. (2001). Collective Rationality And Collective Reasoning. Economics and Philosophy, 20(2): 409-416.

29. Muthia, Fella. Ardhi. (2014). Pengaruh Moral Pajak Dan Budaya Pajak Terhadap Kepatuhan Pajak. Jurnal Ekonomi, 1-10.

30. Mustikasari, E. (2007). Kajian Empiris Tentang Kepatuhan Wajib Pajak Badan diPerusahaan Industri Pengolahan di Surabaya. Simposium Nasional Akuntansi X, 10(1): $1-10$. 
31. Nasucha, Chaizi. (2004). Reformasi Administrasi Publik: Teori dan Praktik. Jakata: Gramedia Widiasarana Indonesia.

32. Nugroho, Aditya., Andini, Rita., Raharjo, Kharis. (2016). Pengaruh Kesadaran Wajib Pajak dan Pengetahuan Perpajakan Wajib Pajak Terhadap Kepatuhan Wajib Pajak Dalam Membayar Pajak Penghasilan. Journal Of Accounting, 2(2): 1-13.

33. Noormala., Sheikh., Obid.(2008). Voluntary Compliance: Tax Education Preventiv. International Journal of Marketing, Financial Services \& Management Research, 2(8): $12-$ 23.

34. O'Donovan, G. (2002). Environmental Disclosures In The Annual Report. Accounting, Auditing \& Accountability Journal, 15(3): 344-371.

35. Pratiwi, I. G. A., Setiawan, P. E. (2014). Pengaruh Kesadaran Wajib Pajak, Kualitas Pelayanan, Kondisi Keuangan Perusahaan, Dan Persepsi Tentang Sanksi Perpajakan Pada Kepatuhan Wajib Pajak Reklame Di Dinas Pendapatan Kota Denpasar. Jurnal Akuntansi, 6(1): 139-153.

36. Pratiwi, P. S. (2016). Pengaruh Pemhaman Peraturan, Administrasi, dan Sanksi Perpajakan Pada Kepatuhan Wajib Pajak Hotel di Kota Denpasar. E-Jurnal Akuntansi Universitas Udayana, 16(32): 1771-1799.

37. Pranata, Putu Aditya., Setiawan, Putu Ery. (2015). Pengaruh Sanksi Perpajakan, Kualitas Pelayanan dan Kewajiban Moral Pada Kepatuhan Wajib Pajak. E-Jurnal Akuntansi Universitas Udayana, 10(2): 456-473.

38. Erly Suady. (2006). Perpajakan Edisi 2. Jakarta: Salemba Empat.

39. Sentanu, I. N. W., Setiawan, Putu Ery. (2016). Pengaruh Kualitas Pelayanan, Kewajiban Moral Dan Sanksi Perpajakan Pada Kepatuhan Wajib Pajak Hotel. E-Jurnal Akuntansi Universitas Udayana, 16(1): 306-332.

40. Rahayu, S. (2009). Pengaruh Modernisasi Sistem Admnistrasi Perpajakan Terhadap Kepatuhan Wajib Pajak. Jurnal Akuntansi, 1(2): 119-138.

41. Rohmawati, A. N. (2012). Pengaruh Kesadaran, Penyuluhan, Pelayanan, dan Sanksi Perpajakan Pada Kepatuhan Wajib Pajak Orang Pribadi. Jurnal Akuntansi, 1(2): 11751188.

42. Robbins, S. P., Timothy, A. J. (2008). Perilaku Organisasi (OrganizationalBehavior). Jakarta: Salemba Empat.

43. Saputra, R. (2015). Pengaruh Sanksi, Kesadaran Perpajakan, Dan Kualitas Pelayanan Wajib Pajak Terhadap Kepatuhan Wajib Pajak Bumi Dan Bangunan (Studi Empiris Pada Wajib Pajak Kabupaten Pasaman). Skripsi. Universitas Negri Padang.

44. Simanjuntak, T. H. (2009). Kepatuhan Pajak (Tax Compliance) dan Bagi Hasil Pajak dalam Perekonomian di Jawa Timur.JESP,1(2): 1-11.

45. Sanjaya, Adi Putra. (2014). Pengaruh Kualitas Pelayanan, Kewajiban Moral dan Sanksi Perpajakan Pada Kepatuhan Wajib Pajak dalam Membayar Pajak Hotel. EJurnal Akuntansi Universitas Udayana, 7(1): 207-222.

46. Sugiyono. (2016). Metode Penelitian Bisnis. Bandung: ALFABETA BANDUNG.

47. Sutrisno Hadi. (2000).Analisis Regresi. Yogyakarta: Andi Offset.

48. Ulupui, I. G. K. (2004). Pengaruh Partisipasi Anggaran, Persepsi Keadilan Distributif, Keadilan Prosedural, dan Goal Commitment Terhadap Kinerja Dinas. KINERJA, 8(1): 163-173.

49. Verboon, P., Dijke, M.V. (2007). A Self-Interest Analysis of Justice and TaxCompliance: How Distributive Justice Moderates the Effect of OutcomeFavorability. Journal of Economic Psychology, 28(6): 704-727.

50. Wenzel, Michael. (2002). The Impact of Outcome Orientation and Justice Concern on Tax Compliance: The Role of Tax Payers Identity. Journal of Applied Psychology, 87: 629-645.

51. Widyawati, Ida Ayu. (2017). Pengaruh Komitmen Organisasi Pada Kinerja Manajerial Dengan Locus Of Control Sebagai Variabel Moderasi.E-Jurnal Akuntansi Universitas Udayana, 19: 311-336. 